\title{
Invisible Women's Barrier as The Glass Ceiling Phenomenon in House of Representative of Indonesia
}

\author{
Nony Natadia Ernel \\ University of Indonesia, Indonesia
}

\begin{abstract}
The problem of women often discussed in each scope of research. Although Indonesia as a country that involves itself as a democratic country, in fact, it does not bring more women to obtain a high position in each commission. In 2014-2019 legislative elections, they can only be placed in the position of vice chairman of the commission. According to the Inter-Parliamentary Union data show that Indonesia just ranked in 102 for the women's representation in parliamentary. While in the Southeast Asia region Indonesia only places at number seven. The problem that arises turns out among the women who seat in The House of Representatives of the Republic of Indonesia (DPR RI) have a closeness to the political elite, as known as political dynasties, followed by women entrepreneurs, and also public figures. So by using Cotter's glass ceiling criteria (2001), it can attract gender and sex identity, which is still a benchmark to, came into the politic. This has also been proven to be a political world where women are labelling as a second sex. Therefore women cannot support themselves in a fair leadership position but must also be supported by all the elements which starting from the government, political parties, to the perspective of the people themselves.
\end{abstract}

Keynote: women, representation, parliament, glass ceiling, quota

\section{Introduction}

In 1955 as a first participation woman at the formal political arena, the Indonesian Women's Congress started the effort in 1928. The effort was achieved not instantaneously because women's political awareness had grown since the first Women's Congress in Yogyakarta 1928. The highest peak of women's presence could be seen as the Indonesian president served for 4 years from July 2001 to October 2004. At the beginning of her tenure, the international media doubted her presence to replace Gus Dur because her background only a housewife who was not comparable with the other Asian women political fighters such as Cory Aquino, Aung San Suu Kyi, and Benazir Bhutto, although some of these figures were present against the background of the influence of husband or father (Sen: 2002). During her tenure, the emerging criticism exacerbated policy that was deemed unfavourable to women, as seen by her failure to bring women's issues as central issues. Megawati is considered a female leader who was not gendered sensitive, for instance, the problem of migrant workers 
abroad who do not receive special attention and are unable to handle migrant workers who have been displaced by Nunukan (East Kalimantan) (Soetjipto: 2005). The impact her lacked sensitivity, Megawati was defeated by her political opponents from the military Susilo Bambang Yudhoyono who came from the new Democratic Party with only $39.4 \%$ of the votes in the 2004 presidential election (Carter Centre: 2004).

Although in the legislative position women have existed since the emergence of Khofifah Indar Parawasna ((1992 - 1999) and Fatimah Achmad (1997 - 1999) but nowadays only these two women have been able to be in the highest position in the Indonesian Parliament by serving as deputy chairman at The House of Representatives of the Republic of Indonesia (DPR RI). the presence of women in politics in Indonesia is still weak, even though in legally formal, presenting a fair and open women's political life contained in the Republic of Indonesia Law Number 39 of 1999 concerning human rights, so the electoral system, party, election of legislative members and executive appointment system and the judiciary for women's representation should be proved, which supported by Election Law No. 12/2004 concerning a minimum allocation of $30 \%$ women to sit in legislative institutions. In fact, they are still not be calculated for strategic positions. This paper tries to see the phenomenon of women's presence in the legislature in Indonesia who have to face the glass ceiling when they want to reach the highest position in Commission. Reynold (1999) considers that the cause of the occurrence of glass skies is a scourge for women in strategic positions caused by several factors: social culture, political culture, regime of a country, and also political institutions, by finding that the problem faced by women is institutional system problems, as well as religion.

On the other hand, the condition of Indonesia encounter with the cultural problem and a view that women have only need to stay in the domestic area, meanwhile the circle of the political environment, it is activities that are inappropriate for women because of perceived, dirty, and rude politics. Causing the presence of women in the legislature still not having an impact on policies stand with women, the pattern of views given by men who judge women unable to give right decisions even though they are in a strategic position but they often ignore regardless of women's issues relating to maternal mortality, the issue of layoffs of women workers, violence against women, not to mention the added religious issues such as inheritance rights, divorce, polygamy (husbands who get married while still having wives), are problems of complicated problems that are difficult to touch and experience change as a result of views that issue it is only a low politics issue. So in this paper we will discuss the process of open participation of women in politics, the presence of women who are still limited in number, and the emptiness of women in a strategic position as an obstacle to women's political participation.

\subsection{Method}

The presence of women to enter politics is faced with challenges. Lovenduski (2008) said the challenge was: first, the resources needed to enter politics were still weak. Women are poorer than men and women are not placed in good positions that support political activities. Second, women have little time in political activities due to social construction, which 
requires them to have a double burden to take care of the domestic area first. Third, the view that political responsibility is categorized as a male task, which makes it difficult for women to pursue political caries and also hinder their recruitment that comes forward. While Lijphart (1991) found democracy with a higher proportion of women in the legislature issued more legislation to benefit children and women. In accordance with what Dahlerup (2005) explained, the reason for the need for representation of women by justice arguments is that half the world's population are women, so women have the right to collect half of the seats available in politics, and experience arguments because women have biologically different experiences and social. Third is the argument about interest groups, women and men having interests that are indeed disputed and therefore men cannot represent women. Fourth, the importance of women who good position in politic will be role models for other women to be active in the political sphere.

If we look at the literature that discusses the importance of the presence of women, especially in a strategic position in the legislature, it appears in what Lisa Vetten (2016) wrote entitled Political Representation make Women 'Leson from South Africa which explains that the election was free from Apartheid since in 1994 brought women to power into policies to end violence against women and children, and then had an impact on the issuance of the Law on Domestic Violence in 1998. Thomas (1991) in Reynolds (1999) found that the United States legislature with a higher number of women influencing the number of budget policies that take sides and includes the management of women, children and families.

Although the involvement of women can be an effort to solve the problem of women, but when women in Indonesia have succeeded in entering and sitting in the parliamentary seat, it does not make them really get a position to vote in decision-making and decide on a policy. Even in a commission they are not given space to voice women's issues and it is not uncommon for male legislators to overlook what women convey. Women legislators must face the risk of social and psychological punishment that is often associated with nonconformity, underestimation, and widespread failure as a reward they must face (Kirkpatrick 1997: 15). In this paper the author tries to include a case about the lack of active presence of women even though it has been sitting in the legislature based on the problem of the glass ceiling, which is considered as a barrier for women to take part in the political world such as parliament. Conceptually, the glass ceiling is an artificial obstacle for the advancement of women or minorities. There are obstacles due to the discrimination of those who are prosperous and disadvantaged. In addition, the glass ceiling phenomenon is a barrier that invisible to women and minor to rise above the ladder as in a strategic position in the corporation, apart from the qualifications they have. (Federal Glass Ceiling Commission 1995b: 4).

Cotter (2001) divides the glass ceiling barrier criteria into four parts: first, the impact of gender or race differences that cannot be explained by job characteristics that are relevant to someone, besides, sometimes the glass ceiling problem appears not based on education, past experience, to motivation, it is precisely the scourge that in deciding someone's position the judgment is placed on the status of one's marriage which in turn gives birth to a sense of 


\section{lachess}

discrimination to the effect on someone who has experience but the quality is not considered. Secondly, putting gender inequality as a tool to dispose of women in a position so that they cannot reach the peak of their career, meaning that the higher a position offered, the more visible the hierarchy of power that encourages someone to be chosen based on interests and the clearer discrimination. Third, the impact of a hierarchical hierarchy, when women are difficult to position in high positions the phenomenon of efforts to promote them is also a problem that appears from the glass ceiling phenomenon, as Cotter (2001: 6) states that at the stage of promotion between male candidates and women often have a percentage of the number of candidates who are nominated more than women, this indicates that the view of sex is one of the bases on how someone is chosen to be promoted. The final criterion, it is necessary to look at the career paths of men and women, for the road to the middle to the highest levels of gender differences can also be a problem in the hierarchy of a certain position or position (Folke: 2016). Although there are already several measuring instruments to look at the glass ceiling issue in this paper, the author looks more at the presence of women in formal political positions, so this paper relies on data collected from the results of the 2014-2019 legislative elections, involving resource persons who are able to explain about women's issues to achieve strategic positions in practical politics.

\section{Democracy and Women's Participation}

When Indonesia underwent a period of democratic transition in the era of President Abdurahman Wahid (Gus Dur), the position of women in formal politics seemed to begin to appear clearly before the public. It should be remembered, that in the previous period namely the New Order regime, Soeharto was considered to be more focused on economic development in order to maintain state stability, whereas in state development seen through a technocratic model, high economic growth had an impact on neglecting the questions of justice, which eventually occurred suppression of political participation. (Huntington, Nelson: 1984). The presence of women in Indonesia has experienced ups and downs in its involvement, especially in politics. When the New Order period with the concept of a single majority party, representation of women in legislative institutions and state institutions tended to be weak because of the dominant interference by party leaders at the central level by certain elites who only involved people from the vicious circle. As a result, the impact on the minority of women who occupy important positions is only those who have family relations or relatives who are very close to officials and holders of power, according to John Gaventa (2006) power cube will refer to the way power manifests itself, namely visible power, hidden power, and invisible power, the power then will only bring some women into strategic political positions including being legislated. Through the mouthpiece of a proportional electoral system that does not elect candidates openly but with symbols, as a result, then some of the women do not go through the stages of selecting well on their candidacy in political activities, and those who appear on the surface do not have the ability to articulate the interests of their constituents. and unfortunately the dominance of kinship and elite 
political influence is still occurring in Indonesia even though it has attributed itself as a democratic country with an open proportional system as it is today.

Comparing with the United States, the women's movement born since the 1840s under the leadership of Elizabeth Cady Stanton and Susan B. Anthony they have sternly made efforts by gathering various groups of women from workers to the educated, and the wives of elites to get their rights as citizens through (NSWA) National Women Suffrage Association. Then joined the organization founded by Lucy Stone's American Woman's Suffrage Assistance to conduct a campaign effort and they even had to experience confinement due to the actions of female activists who were considered not pro against the government during the war. Through the spirit of fighting for women's rights then it can produce the 19th amendment, namely given the right to women to vote (Mutiara: 2005).

While in Indonesia, even though from the beginning they did not feel discrimination with the prohibition to vote and be elected in election contestation, but still the appearance of women in the political world experienced a fluctuating wave. If in the New Order era led by Soeharto women experienced confusion, it was coded earlier, when before this country was born with the name of Indonesia, the women's movement was accepted and got a good place because it was pro against the independence of the country. The presence of women against colonialism was demonstrated by the first struggle through the first Indonesian Women's Congress in Yogyakarta on December 22-26, 1928 which produced the Indonesian women's union organization (Indonesian Perempoean Association). After this period the struggle of the women's political movement continued to increase. Demands that Indonesian women have the right to vote and be elected in important bodies such as the Volksraad. The struggle made Indonesian women in colonial times then have an existence, namely in 1938 the colonial government gave passive voting rights (passief kiesrecht) to four women to become city councils (gemsete road). Gradually later in 1941 led by the Chair of Indonesian Wife Soenarjo Mangun Poespito the demand was made again with a motion not to believe in the colonial government so that Indonesian women were given active suffrage (Aktief kieserecht) (Poskapol: 2013). Indonesian women have carried out various struggles to acquire women's interests and even in the colonial period various women's movements took part to help fighters with various roles, such as helping to heal soldiers, sew army clothes, and until the Japanese colonial period in 1942 women had to be under the interests of the invaders, then the Japanese formed an army of armed women such as Laskar Putri Indonesia (LPI), the Center for Indonesian Women's Conquests (PTPWI), and the Indonesian Women's Association (Perwari) as a result of women's depression in the pressure of Japanese colonialism, but women did not dissolve and put aside gender interests and then actively participated in the independence movement to be able to enter into the basic formulation of the state in 1945.

Unfortunately the spirit of the struggle of the Indonesian women's movement, which was present very critically at the beginning of the formation of this country, seemed to be experiencing a setback. Until 2018 women who entered the House of Representatives of the Republic of Indonesia (DPR RI) gave a question mark. The portion of the legislator's seat that should be filled by women, but in fact the placement of women in each commission is not 


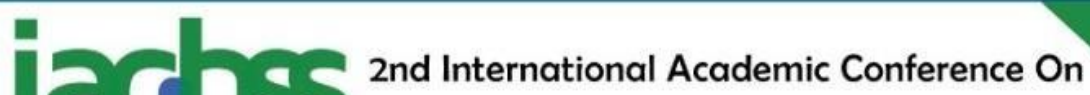

determined based on the urgency of the policy that wants to be born. Critics of the pessimism of democracy delivered by Diamond, Linz, and Lipset mention the instability of the democratic regime in third world countries due to the combination and interaction between factors that lead to weak legitimacy and low effectiveness. As a result, new democracy must be in a vicious circle. What countries adopt a democratic system will be stable if: first, the ability of political elites such as party leaders, military leaders, business leaders, can cooperate in overcoming the problems faced by their communities and refraining from exploiting problems to gain political gain, or material directly for the benefit of yourself. Second, democratic stability is influenced by the public's ability to differentiate between a regime or government, because sometimes nostalgia for an authoritarian system will be dangerous and it will kill the democratic regime (Huntington: 1991). This is like the description of what happened in Indonesia during the 32-year Soeharto regime, causing women's organizations to die from the New Order to impose sexual politics on women based on vaginal detachment, where formal and informal political activities carried out by women have the potential to damage national life. for example, the New Order regime strongly challenged the presence of Gerwani who fought for political rights, their existence was regarded as communist women by the state and society (Wieringa, 2010). Not only that, the practice of sub-alternative towards women's engagement is also done through tactics with the establishment of corporate countries such as Dharma Wanita, PKK, and Wisma Village, so that the government's reach is more to regulate women's involvement in order to minimize and then construct the public's thinking that women are better in private space from public spaces.

The impact of the long period of power that the Soeharto regime had on women, made the presence of women and their involvement in politics after the transition to democracy seemed like half-hearted. Behind a democratic system that creates a more open government, it should be able to encourage an increase in women in the legislature. This is because of the renewal of open politics such as a proportional electoral system, the application of quotas for women, to the government's structural policies that are gender-friendly. The position of women in formal politics was echoed in article 188 of the Beijing Platform, this brought women into positions that were calculated through affirmative action policies, in Indonesia itself the policy was stated since the enactment of Law Number 10 of 2008 instructing the party to at least include $30 \%$ of women to become members of the legislative elections, and in article 55 paragraph (2) mentioning the position of women who are no longer in the shoes number with the zipper system. Dahlerup (2005) explains the reason why the need for women representation is caused by the justice argument because half of the world's population are women so she has the right to control half of the available seats in political institutions, secondly the experience argument because women have different experiences both biologically and socially. Thirdly, the interest group arguments, women and men have interests that are partly contradictory and men cannot represent women. Although there is a reason that opportunities have been opened for women, it is also important for women to have a maximum role in their representation in the legislative chair. 
Although the representation faucet has been an open, women still face social barrier, especially to become political actors, they are women poorer than men and tend not to be placed in positions - positions that support political activities. Secondly, various kinds of restraints in domestic areas have resulted in women having little time to engage in politics such as family responsibilities as a result of social constructions, which require full attention and are typically carried out by the government to reduce their time for political activities. Third, political duties are categorized as male duties, which prevents women from pursuing political caries and also hinders their recruitment that comes forward. Subono said that due to social construction in the midst of the community made women trapped in unfair division of labour, women had to work since the morning to take care of the needs of their husbands and children, until evening. Unfortunately, the work they get is less appreciated by their partners, their husbands feel that their role is only limited to working and giving money for family needs, without taking part in household work that should be done together, which then makes women have little time to equip themselves in practical political activities. (Interview, Nur Imam Subono a lecturer in the Department of Political Science, University of Indonesia). The challenge then makes women not only difficult to enter into parliament but also shows that there are still other gaps facing women, namely the dominance of masculine structures that ensnare women to be unable to be in strategic positions in parliament.

\section{Represented of Women Only Limited to The Amount}

Suzanne Dove (2006) mentions that there are several main components in women's political representation: (a) the presence of parties representing (members of the DPR, Organizations, Movements, or state bodies), (b) the parties they represent (constituents, clients), ( c) the existence of something that is represented (opinion, perspective, and interests), (d) settings where the activity of representation occurs (political context). In terms of quantity, parliament in Indonesia has a positive view on the presence of women being legislated. In 2004 the number of women who entered the DPR RI was only $11.05 \%$, and in 2009 the number had increased by $17.83 \%$, with the number of women in the composition of the Prosperous Justice Party (PKS) being the lowest number of women, only $5.3 \%$ and vice versa the Indonesian Democratic Party of Struggle (PDIP) contributed the highest number of female attendance at 24.3\%. The United Nations Development Program (UNDP) said that:

The higher number of women's representation in the DPD RI indicates a positive trend that exists amongst voters in Indonesia, who do not appear to have a strong gender bias against women politicians. The voters have shown confidence in women candidates by electing them to represent their interests in the DPD RI. (UNDP: 2010)

Unfortunately the existence of women in parliament, who are expected that able to slowly reach the critical mass number which determine political decisions does not actually show a proud number, instead decreases in the next period. The lower of women legislative members indicates this in the

period 2014- 
2019 only reaching $17.3 \%$ (after termination / and replacement of positions).

\begin{tabular}{|l|l|l|l|}
\hline $\begin{array}{l}\text { General } \\
\text { Election }\end{array}$ & $\begin{array}{l}\text { Total Number of } \\
\text { MPs }\end{array}$ & $\begin{array}{l}\text { Total Number of } \\
\text { Woman MPs }\end{array}$ & $\%$ \\
\hline 1997 & 500 & 54 & 10.80 \\
1999 & 500 & 45 & 9 \\
2004 & 550 & 61 & 11.05 \\
2009 & 560 & 101 & 17.86 \\
2014 & 560 & 97 & 17.3 \\
\hline
\end{tabular}

Source: Kemitraan bagi Pembaharuan Tata

Pemerintahan, 2011 dan Puskapol UI

In the Inter-Parliamentary Union data, the position of Indonesian women's representation in the world in the 2014-2019 period is only at position 102 out of 193 countries, this is quite ironic considering Indonesia is one of the world's number three population with a democratic system. If seen in the previous period, namely in 2009, there were 101 women in the DPR. However, before the minimum number of female candidates was determined through the law of political parties, in 1997 the number of female representation was not so high as only 54 people, but IPU had counted Indonesia as a country in the world with the representation of women in position 40 (IPU: 1997).

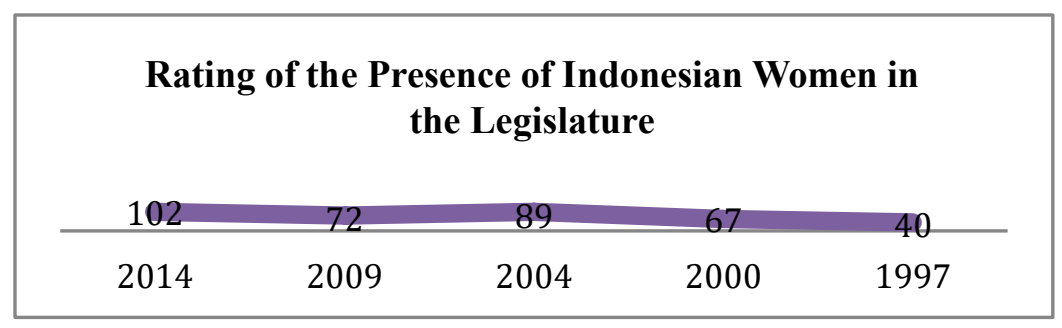

Compared with other countries in Southeast Asia, Indonesia must admit that the presence of women who are included in the parliament is still weak, the IPU data record (2018) shows that Indonesia must be satisfied with the presence of women in politics which is only in position 7 of 11 existing country by looking at the number of women in Parliament.

\begin{tabular}{lll}
\hline N Country & Chamber & Electoral Percent \\
o. & Quota For age of Positio \\
\hline
\end{tabular}




\begin{tabular}{|c|c|c|c|c|c|}
\hline & & & Women & Womei & \\
\hline 1 & Brunnei Darussalam & Legislative Council & No & 9.09 & 10 \\
\hline 2 & Cambodia & National Aseembly & No & 20 & 6 \\
\hline 3 & Indonesia & $\begin{array}{l}\text { House of } \\
\text { Representatives }\end{array}$ & Yes & 17.3 & 7 \\
\hline 4 & $\begin{array}{l}\text { Lao People's Democratic } \\
\text { Republic }\end{array}$ & National Assembly & No & 27.52 & 3 \\
\hline 5 & Malaysia & $\begin{array}{l}\text { House } \\
\text { Representatives }\end{array}$ & Yes & 13.9 & 8 \\
\hline 6 & Myanmar & $\begin{array}{l}\text { House } \\
\text { Representatives }\end{array}$ & No & 10.16 & 9 \\
\hline 7 & Philippines & $\begin{array}{l}\text { House } \\
\text { Representatives }\end{array}$ & No & 29.45 & 2 \\
\hline 8 & Singapore & Parliament & No & 23 & 5 \\
\hline 9 & Thailand & $\begin{array}{l}\text { National Legislative } \\
\text { Assembly }\end{array}$ & Yes & 5.28 & 11 \\
\hline 10 & Timor-Lesta & National Parlement & Yes & 33.85 & 1 \\
\hline 11 & Viet Nam & National Assembly & No & 26.72 & 4 \\
\hline
\end{tabular}

Souces: IPU 2018 and Puskapol UI 2014

The Interesting evident in data above is from the highest position for Southeast Asia filled by Timor-Leste and the seventh place fill with Indonesia. In terms of the system, which applies the quota of women's representation, only the two countries provide space for women, while for the other five countries such as the Philippines, Lao People's Democratic Republic, Viet Nam, Singapore and Cambodia it does not provide a quota policy for women but have participation rates women who are higher than Indonesia. What is interesting about the condition of women in parliament in Timor-Leste who experienced a restoration of independence on May 20, 2002, legally it turns out that since the beginning the Timor-Leste constitution guaranteed the principle of equality and non-discrimination for all citizens regardless of gender and race Article 19, also in Article 17. The constitution guarantees equal rights and responsibilities for men and women both in the household, political participation, economy, social and culture, and Article 63 of the Constitution also expressly states that participation between women and men in politics are the basis for democratic practice in Timor-Leste. Other equality support also comes from national institutions that promote women's issues and interests into the State Secretariat for the Promotion of Equality (SEPI) which is under the mandate of the Prime Minister (Ani Soetjipto: 2014).

In Timor-Leste's social culture is still thick with the bidding of a paternalistic society, as well as Indonesia, as a result of political power before the reform era. In Indonesia, constitutionally the spirit of women's participation is stated in the mandate of Law Number 7 of 1984 and the constitution of article 27 of the 1945 Law to participate in decision-making but due to patriarchal culture of women who have not been able to make independent 
decisions because they are influenced by husbands, superiors, friends certain family or group. This is because women have challenges for participation in the political field because they must be able to combine themselves to act as mothers, as well as citizens who must be able to work productively and play a role in the public space.

The cultural conditions of Indonesian society, the role of the mother are often praised in various poems, songs, speeches, and religious lectures. In fact, many mothers in Indonesia are in a life without good fortune such as lack of blood due to frequent childbirth, overwork, lack of nutritious food and education, domestic violence, public abuse, workplace violence, and trafficking in women. This is the problem experienced by Indonesian women who have not fully received a positive response from policy makers. Although men can raise the issues with a female perspective, it turns out that until now women are still victims of the above actions. As in the 2018 Annual Note (CATAHU) of women's national commission (Komnas Perempuan) stated that there were still acts of violence against women in three domains: personal / private, public / community, and countries with a number of violence reaching 348,446 cases of violence. For the case of trafficking, there are 4.5 million Indonesian workers abroad; around 1.9 million of them women who do not have documents and are often the object of sexual trade, especially in Malaysia, Taiwan and the Middle East ${ }^{1}$. In the case of maternal deaths, Indonesia still has to work hard because of the evaluation report of the Millennium Development Goals (MDGs) in 2015, an average of 100,000 mothers still had 307 who died from childbirth and this value was far from the target of 110 mothers, followed by the wages of women who have not been fair, and the level of female illiteracy that still reaches $2,258,990$.

Some examples of the above issues agenda should be a problem that needs to get special treatment for women members of parliament in Indonesia. When they are in the position of leaders they are at least able to convey what is the problem of women when they sit and on the agenda of the meeting. Through the issuance of the General Election Commission Regulation (PKPU) No. 7 of 2013 which regulates the nomination of a minimum of $30 \%$ in each region as an effort to destroy the special space for men in seizing seats in the legislature by forcing parties to fulfil the nomination quota will be one strategic step to encourage female candidates. The reality is that when the party seeks to include women in the legislative nomination, the party does not see this quality in terms of women as indicated by the presence of women in the DPR RI who tend to rely on certain backgrounds rather than experience as activists, as well as in organizations.

The Base of Women's Election in the Indonesian Parliament

\footnotetext{
1 Data is obtained from the U.S. Diplomacy in Action report. Department of State in Office to Monitor and Combat Trafficking in Persons (2018 Trafficking in Person Report). It is noted that Indonesia is one of the countries that does not yet have a minimum standard to minimize the act of trafficking.
} 


\section{lachss

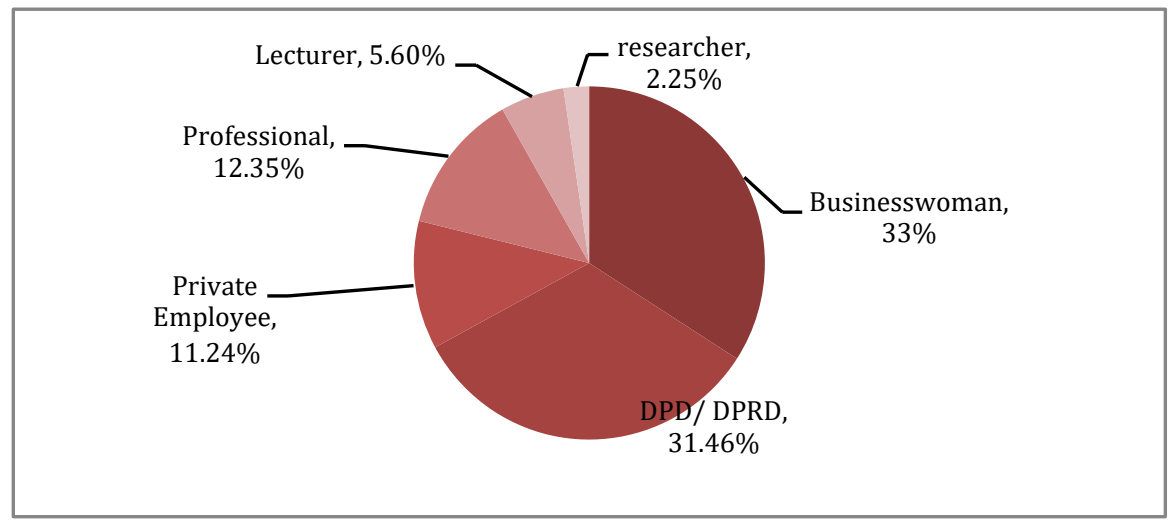

Souces: Puskapol UI 2014

In addition to the data above, in 2014 found the number of incumbents who sat back only reached $40 \%$ and the rest filled with new faces, with found $46.75 \%$ of women elected turned out to have closeness with the political elite (PuskapolUI: 2015). Although kinship is one way for women to enter into practical politics, to be part of a high position is not easy, when in a political world that has been considered hard and tends to be masculine then forms a transparent wall for women in a strategic position within parliament. The number of women who are a little reason for women not being able to be promoted into leadership positions as happened to members of the Indonesian House of Representatives today until 2019 only three women sit as deputy chairmen of the Commission in the DPR RI.

\begin{tabular}{|c|c|c|c|c|}
\hline No & Commission (Field of Work) & $\begin{array}{l}\text { Total } \\
\text { Members }\end{array}$ & $\begin{array}{l}\text { Women } \\
\text { Member } \\
\text { S }\end{array}$ & $\begin{array}{l}\text { Women } \\
\text { Leader }\end{array}$ \\
\hline 1 & $\begin{array}{l}\text { Commission I (Defence, Intelligence, } \\
\text { Foreign Affairs, Communication and } \\
\text { Information) }\end{array}$ & 51 & 5 & - \\
\hline 2 & $\begin{array}{l}\text { Commission II (Home Affairs, Regional } \\
\text { Autonomy, State Apparatus and } \\
\text { Bureaucratic Reform, General Elections, } \\
\text { Land and Agrarian Reform) }\end{array}$ & 44 & 7 & $\begin{array}{l}1 \quad \text { (vice } \\
\text { chairperson) }\end{array}$ \\
\hline 3 & $\begin{array}{l}\text { Commission III (Law, Human Rights, and } \\
\text { Security) }\end{array}$ & 51 & 3 & $\begin{array}{l}1 \quad \text { (vice } \\
\text { chairperson) }\end{array}$ \\
\hline 4 & $\begin{array}{l}\text { Commission IV (Agriculture, Plantation, } \\
\text { Forestry, Marine, Fisheries, Food) }\end{array}$ & 47 & 6 & - \\
\hline 5 & $\begin{array}{l}\text { Commission V (Transportation, Public } \\
\text { Works, Housing, Development of Rural } \\
\text { and Underdeveloped r Regions, } \\
\text { Meteorology, Climatology } \\
\text { Geophysics) }\end{array}$ & 51 & 9 & - \\
\hline
\end{tabular}




\section{lachss}

\begin{tabular}{lllll}
\hline 6 & $\begin{array}{l}\text { Commission VI (Commerce, Industry, 52 } \\
\text { Investment, Cooperatives, SMEs and } \\
\text { SOEs, National Standardization) }\end{array}$ & 5 & - \\
\hline 7 & $\begin{array}{l}\text { Commission VII (Energy and Mineral 50 } \\
\text { Resources, Research and Technology, }\end{array}$ & 5 & - \\
\hline 8 Environment) & $\begin{array}{l}\text { Commission VIII (Religious, Social, 46 } \\
\text { Women's Empowerment) }\end{array}$ & 13 & - \\
\hline 9 & $\begin{array}{l}\text { Commission IX (Manpower and 50 } \\
\text { transmigration, Population, Health) }\end{array}$ & 18 & - & (vice \\
\hline 10 & $\begin{array}{l}\text { Commission X (Education, Culture, 47 } \\
\text { Tourism, Creative Economy, Youth, } \\
\text { Sports, Library) }\end{array}$ & 18 & 1 \\
Commission XI (Finance, Development 48 \\
Planning, Banking)
\end{tabular}

This table shows that the impact of the limited number of attendance of women in parliament has not yet increased, causing the number of women in the six commissions to decrease, such as in Commission I, Commission II, Commission IV, Commission IX, Commission XI, while Commission III has stagnant representation. Compared to the previous year, there were no women sitting as chairpersons in the 2014-2019 periods. While in 2009 2014 there was one woman who led the commission IX and one vice chairperson was in the same commissioned.

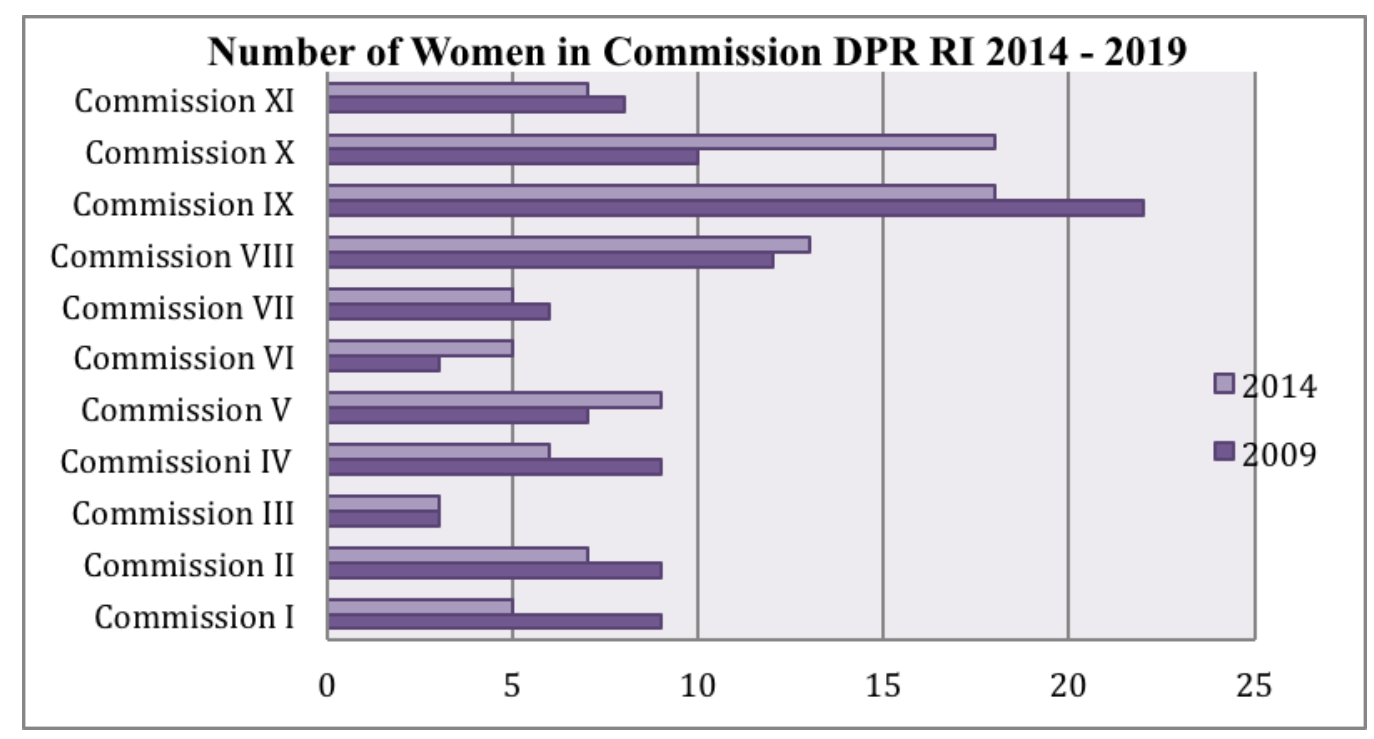

Because of the lack of female attendance in strategic positions, according to three of the six members of the Regional Representatives Council (DPRD) of the Riau Islands Province said that they are often unable to lobby and approach faction officials, they are even reluctant to 
express their opinions and arguments, and the women members of the legislature still do not know why the affirmative action policy was born by placing $30 \%$ of women in parliament, and when author asked about what programs were targeted that they brought into parliament as aspirations from the community it appeared that they did not have a focused policy to gender issues, and when we looked into the background of five of the six legislative members in the province they were not too struggling for legislative seats because they have sufficient capital such as closeness to the elite either as the wife of the mayor, or the wife of the party's head, and entrepreneur's wife (Interviews: Yuniarti Pustoko Weny from PDIP, Suryani from PKS, Ririn Warsiti from Gerindra Party, Member of Riau Islands Province DPRD 2014 2019). When Indonesian women must be trapped in the struggle to enter, but also to be recognized by being in a strategic position is also very difficult. This is different from what happened in Rwanda, women's political participation has been facilitated by the constitutional mandate and work of key institutions, namely the Ministry of Gender and Family Advancement, the National Parliament Forum, and the Office of Gender Monitoring. The National Women's Council (NCW) is a forum for women's participation in national and government development. Since the age of 18 Rwandan women and girls have been members of the NWC operating at the village, sub-district, district and sector levels to mobilize women's decision-making and they are also given knowledge of the importance of women's presence in an election this is simulated through the selection of NWC positions.

Lena Maryana, as member of Commission IX who has participated in legislative battles for the six times, since 1992, has also been a member of the 2004 Legislative and Presidential Election Special Committee (Pansus), stating that dynastic political tendencies have been rife since opening this democratic those tap caused by parties that lacked about what we call political will towards integrity that cadres needed to have. This according to Maryana was caused by the rise of political lobbying, and transactional politics as a bargaining tool in participating as participants in legislative elections. When Indonesia implements more open system by using the open-list proportional election system, Marlina said that in Indonesia, despite the euphoria of the openness of rights, it has not been fully able to become a state with a deliberated election system, because the infrastructure, superstructure, and society cannot stand fairly view with equality as a democratic state requirement (Interviews, Lena Maryana Commission IX House of Representatives of the Republic of Indonesia, November 2018). Indeed, unlike the closed-list system, candidates in the open-list system must compete not only with political opponents from other parties but also must compete with candidates from the same party. This often makes political parties release responsibility for each competing candidate, so that the quality of candidates is no longer the main point as representatives sitting in parliament. the absence of this responsibility turned out to be brought into the position of the party and faction commissions, and had never even discussed the importance of women to occupy positions in the leader of a commission that dealt directly with women's issues.

The mechanism for selecting the chairman and deputy chairman of the Commission which quoted from teropongseyang.com Fahri Hamzah as Deputy Chairperson of the House of Representatives (PKS) faction said that the election of commission leaders did not use a by 


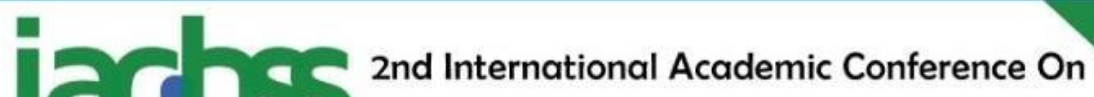

looking from the Great Indonesian Coalition (KIH) as well as the Red and White Coalition (KMP) but depends on the mechanism basis of members and factions, through appointment by means of consensus agreement or through a voting system, candidates are appointed through the appointment of a name recommended by the faction. As a result, the nomination system relied on a faction vote which made it difficult for minority women to lift their position as leaders because women legislators were faced with the fact that they were a little far from the standard so they were not considered candidates for the leadership of the Commission. The political opponents that women must deal to fight for leadership positions include old political players, as well as male members who often speak loudly inside and before sitting in parliament.

The woman who successes to sit as a vice chairman at the Indonesian House of Representatives (DPR RI) Commission II who was previously on commission VIII Nihayatul Wafiro. With a good education background and she also actively voiced argued that women who sat were Parliament with a loud voice and were able to assist in voicing opinions, but they are often passive and only attend formalities meetings, this is then makes them considered not having provision or not worthy to have high commission positions. Women with backgrounds that do not originate from politics and do not have experience in working in organizations often find it difficult to adjust their voice at commission meetings. What makes it difficult for women to break the glass ceiling? Because politics related to men and women who never reach $30 \%$ because of the inability of the community to accept women, Secondly, consideration of the dominance of women's political faces is only filled by women who control the political position and do not fit the quality to fight for seats in parliament so that the compilation of their negotiations is still related to those who are unable to push forward, so women can learn easily. Only a small proportion, are resulting from political parties that do not provide cadre with special treatment for women to be able to stand on par with members who support men.

\section{Conclusion}

For women to penetrate into barriers that invisible to at parliamentary, not only can be done by loudly voicing what they are fighting for as long as they sit in the legislative seat, but it requires by long process that needs to be prepared since being part in the party, with the Law on Political Party No. 2 of 2008 which states that parties pay attention to gender equality and justice in political education. However, until now the provisions have only been given to women who have become legislative candidates who have indeed entered the provisions of the Election Law Number 10 of 2008 concerning Elections and are contained in Article 53 that the list of candidates for the legislature contains at least $30 \%$ representation of women. Problems being worsen when political parties have only taken women candidates randomly, on the basis of money capital, as well as the proximity of elites without regard to and preparing women to have quality. Legislative women oftentimes got the view that they were only a minority group that was present enough to fulfil the conditions for the implementation 


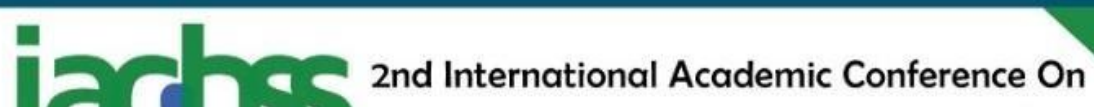

of the quota system and in discussing issues relating to the issue of women being victims, it should also require a woman's perspective to resolve the problem.

Open-list for some women is the way to make attempting in fighting for seats more fair, but in fact when the system is open, women who enter are only limited to those who have political relations, person who have good economic capital, or even those who work as public figures. So that today the position of an important commission is still dominated by men. As said by Manon Tremblay, the electoral system is not a single determinant that influences the number of elected women, but combined with other factors in determining. The electoral system forms competition between party candidates, so political parties should prepare candidates with their internal competition based on quality, and then it will affect the party's way of preparing cadres through good recruitment and selecting candidates who have the capability

Finally, efforts that can be made for women to enter into strategic positions and break down the barriers of women experiencing glass ceilings are with the support and awareness of political parties and the government who understand that women's presence is important as a fulfilment of the problems faced by women themselves. That because according to what was conveyed by Dahlerup that women have a policy perspective that will never be same from men. The steps that can be taken are the education of political party cadres through allocating education funds to women cadres, then providing opportunities for women legislators to run for candidacy and be nominated by factions to be chairpersons and deputy chairmen of the commission, and to place women in important positions in Commissions such as III, IV, VII,

\section{References}

VIII, IX, and Commission XI.

1. Andrew Reynolds.:Women in the Legislatures and Executives of the World: Knocking at the Highest Glass Ceiling. World Politics, 51,547-572, 1999

2. Arend, Lijphart.: Debate-Proportional Representation: III. Double Checking the Evidence, Journal of Democracy 2, 42-48, 1991

3. Ani Soetjipto.: The Role of the Parliamentary Women's Caucus in Promoting Women's Participation and Representation: A Case Study in Indonesia and TimorLeste. Jakarta: Kemitraan Bagi Pembaruan Tata Pemerintahan, 25 - 26, 2014

4. Dewi, Ita Mutiara.: Studi Kritis Peran Wanita Dalam Perpolitikan Dunia. Journal Universitas Negeri Yogyakarta [Online],: 5, 2005. Available: https://journal.uny.ac.id/index.php/mozaik/article/viewFile/5536/4799

5. Dahlerup, D.: Increasing Women's Political Participation: New Trends in Gender Quotas. 'In Women in Parliament: Beyond Numbers, ed. J. Ballington, \& A. Karam. Stockholm: International IDEA: 141-153, 2005 
6. Federal Glass Ceiling Commission. 1995a. Good for Business: Making Full Use of the Nation's Human Capital. U.S. Department of Labor. Available: https://digitalcommons.ilr.cornell.edu/cgi/viewcontent.cgi?article=1118\&context=key _workplace

7. Folke, O., \& Rickne, J.: The Glass Ceiling in Politics: Formalization and Empirical Tests. Comparative Political Studies, 49(5), 567-599, 2016. Available: https://doi.org/10.1177/0010414015621073

8. Gaventa, John.: Finding the Spaces for Change: Power Analysis. IDS Bulletin, Volume 37, Number 6,: 23, 2006

9. Huntington, Samuel P. and Joan M. Nelson.: No Easy Choice: Political Participation in Developing Countries, Cambridge: Harvard University Press, 88, 1976

10. Huntington, Samuel P.: The Third Wave: Democratization in the Late Twentieth Century. University of Oklahoma: University of Oklahoma Press, 332-337. 1991

11. Ilyasa Bara.: Proses Pemilihan Komisi Tak Serumit DPR. 2014. Available: http://www.teropongsenayan.com/2282-proses-pilihan-pimpinan-komisi-tak-serumitdpr

12. Khrishna, Sen.: Women In Indonesia: Gender, Equity and Development. Singapore: ISEA, 15, 2002

13. Kirkpatrick, Jeane.: Political Women. New York: Basic Books, 1974.

14. Komnas Perempuan.: Tergerusnya Ruang Aman Perempuan dalam Pusaran Politik Populisme, 1, 2018.

Available:https://www.komnasperempuan.go.id/file/pdf_file/2018/SIARAN\%20PER

S\%202018/Lembar\%20Fakta\%20Catahu\%207\%20Maret\%202018.pdf

15. Lovenduski, Joni.: Feminizing Politics, Cambridge: Polity Press,88, 2005

16. Puskapol.: Panduan Calon Legislatif Perempuan Untuk Pemilu 2014. Departemen Ilmu Politik Fisip-UI: Pusat Kajian Politik, 19-20. 2013.

17. Soetjipto, Ani Widiyani.: Politik Perempuan Bukan Gerhana, Yogyakarta: Penerbit Gava Media, 6-7,2004

18. Subono, Nur Iman.: The Representasi Politik Perempuan Yang Lebih Bermakna. Journal Sosial Demokrasi: Representasi Politik Perempuan Sekedar Ada Atau Pemberi Warna, Issue 6 of the 2nd Year,58, 2009

19. The Carter Center.: Indonesia Election Report, 2004 Available: https://www.cartercenter.org/documents/2161.pdf

20. Tremblay, Manon.: Women and Legislative Representation: Electoral System, Political Parties, and Sex Quotas. Palgrave Macmillan, 2, 2012

21. UNDP.: Women's Participation in Politic and Government in Indonesia: A policy Paper, 3 - 4,2010

Available:http://www.peacewomen.org/assets/file/Resources/UN/partpol_womenspart icipationpoliticsgovernmentindonesia_undp_may2010.pdf

22. U.S. State Department.: Trafficking in Persons Report,226 - 228, 2018

Available: https://www.state.gov/documents/organization/282801.pdf 